\title{
Inddragelse, modstand og forhandling i skole-hjem-samtalen
}

\author{
Stine Helms, adjunkt, Ph.d., \\ Professionshøjskolen Absalon, stch@pha.dk
}

\begin{abstract}
Resume
Denne artikel handler om forældres og elevers muligheder for at inddrage egne perspektiver, forhandle og udfordre lærernes beskrivelser og vurderinger under skole-hjem-samtalerne. I artiklen vises det, hvordan højtpræsterende elever og deres forældres modstand i langt højere grad genkendes og imødekommes, end dette er tilfældet for lavtpræsterende elever og deres forældre, hvis modstand eller forsøg på forhandlinger ofte negligeres. Dette sætter markant forskellige betingelser op for de hhv. højt- og lavtpræsterende elever og deres forældre i forhold til reelt at blive inddraget i skole-hjem-samarbejdet.
\end{abstract}

Nøgleord: skole-hjem-samtale, folkeskolen, forhandling, inddragelse, ulighed.

\begin{abstract}
This article is about parents and students' opportunities to include their own perspectives, negotiate and challenge the teachers' descriptions and assessments during the parent teacher conferences. The article shows how high-achieving students and their parents' resistance are much more recognized and accepted than it is for the low-achieving students and their parents, whose resistance or attempt at negotiation often is neglected. This sets up significantly different conditions for respectively the high- and low-achieving students and their parents in relation to actually being included in the home-school cooperation.
\end{abstract}

Keywords: parent-teacher conference, public school, negotiation, inclusion, inequality.

\section{Indledning}

I 1974 formaliseredes det i folkeskolens formålsparagraf, at skolen er forpligtet til at samarbejde med alle forældre (Ravn, 2011, s. 28), og siden 1970'erne er et godt samarbejde mellem skole og hjem søgt intensiveret fra såvel politisk som pædagogisk hold. Gennem årene er politiske kampagner og pædagogiske tiltag sat i værk for at styrke skole-hjem-samarbejdet, og blandt de mest udbredte tiltag kan nævnes de årlige forældremøder og skole-hjem-samtaler, udviklingen af ForældreIntra (nu AULA), indførelsen af elevplaner, skolebe- 
styrelsessarbejde samt konceptet om kontaktforældre (Dannesboe et al., 2012, s. 9; Akselvoll, 2016). Der har været en stigende opmærksomhed på at se forældrene som en ressource for skolens arbejde med den enkelte elev, og over de senere år betones det både i forskningen (se fx Desforges \& Abouchaar, 2003; Nordahl, 2008) og i skolepolitikken, hvor stor en betydning forældrenes inddragelse i skolen har for elevens skolegang (Akselvoll, 2016). Børne- og undervisningsministeriet (2020) skriver bl.a. følgende:

\section{Forældrenes engagement og indflydelse betyder meget for, at skoledagen bliver god og lærerig for eleverne. \\ Et godt skole-hjem-samarbejde er med til at skabe gode betingelser for den enkelte elevs læring og trivsel og for undervisningsmiljøet $i$ klassen. I et godt skole-hjem-samarbejde bliver forældrene inddraget $i$ skolen. (Børne- og undervisningsministeriet, 2020)}

Skole-hjem-samtalen, der udgør et af de mest centrale tiltag i forhold til at styrke samarbejdet mellem skole og hjem, afholdes på størstedelen af landets skoler en til to gange årligt. Som oftest deltager to af elevens lærere - typisk dansk- og matematiklæreren, elevens forældre og ofte også eleven selv. Skole-hjem-samtalen er således et af de 'steder', hvor forældrene har mulighed for at vise deres engagement i skolen, og hvor skolen omvendt har mulighed for at inddrage forældrene. Det spørgsmål, jeg ønsker at stille i denne artikel, er dog, i hvilket omfang forældre og også elever reelt inddrages i skole-hjem-samarbejdet - med skole-hjem-samtalen som fokus. Dette spørgsmål udspringer af såvel mere kritisk forskning omkring skole-hjem-samtaler som af min ph.d.-afhandling (Helms, 2017), hvis empiriske materiale danner grundlag for denne artikel. I det følgende vil jeg som afsæt for artiklens tema skitsere dele af den hidtidige danske forskning omkring skole-hjem-samarbejde.

\section{Forskningsfeltet}

Et centralt fund i forskningen er, at forældre har forskellige muligheder for at deltage og involvere sig i deres børns skolegang, herunder i skole-hjem-samtalen. Flere tidligere studier tager afsæt i Bourdieus kapitalbegreb og betoner, hvordan forældre har forskellige forudsætninger for involvering og inddragelse afhængigt af deres uddannelsesniveau og graden af kulturel kapital (fx Aarseth, 2014; Akselvoll, 2016; Kryger, 2012; Palludan, 2012). 
Akselvoll (2016) viser for eksempel, at forældre med en høj uddannelsesog kulturel kapital har større mulighed for at være aktive deltagere i skole-hjem-samtalen end forældre med et lavere uddannelsesniveau og en lavere grad af kulturel kapital. Således har førstnævnte gruppe lettere ved at afkode og navigere i de uskrevne 'regler' for passende deltagelse, der kendetegner skole-hjem-samtalen, hvilket betyder, at de ofte er mere aktive i samtalen, mens sidstnævnte gruppe ofte er mere passive (Akselvoll, 2016, s. 141-143). At der netop eksisterer nogle særlige koder for, hvordan forældre forventes at agere under skole-hjem-samtalen, er et andet centralt fund i forskningen. Knudsen (2010) taler om en særlig opbakningsdiskurs som en forventning til forældrene om at støtte op om det, skolen gør, hvorfor det under samtalen forventes, at forældrene tager positivt imod lærernes meddelelser og ikke stiller for mange kritiske spørgsmål. Samtidig taler Knudsen om en særlig ansvarsdiskurs, hvor det forventes, at forældrene også tager ansvar for at afhjælpe eventuelle problemer omkring eleven (Knudsen, 2010, s. 140; se også Ravn, 2011; Kryger, 2015). Dannesboe (2012) betegner fordringen om som forælder at udvise tillid til lærerne og tage ansvar for skolens forventninger, som det at levere et 'passende engagement' (Dannesboe, 2012, s. 103). Knudsen (2010) fremhæver videre, hvordan elevers og forældres muligheder for at udøve modstand mod lærerne begrænses af de muligheder for deltagelse, som tilbydes og accepteres under skole-hjem-samtalen (Knudsen, 2010, s. 127). Vælger elev og forældre at udøve modstand, vil dette således ofte blive anset som et upassende brud på forventningerne om at bakke op og påtage sig ansvaret for lærernes henstillinger til områder, hvor eleven bør forbedre sig (Knudsen, 2010, s. 131-133). Akselvoll (2016) viser i relation hertil, hvordan såvel de kapitalstærke som de mindre kapitalstærke forældre er meget optagede af at gøre et godt indtryk på lærerne og undgå at italesætte eventuel kritik (Akselvoll, 2016, s. 142).

\section{Artiklens ærinde og bidrag}

Et centralt fokus i den kritiske forskning omkring skole-hjem-samtaler og -samarbejde er et ulige magtforhold mellem skole og hjem. Skolen har retten til at beskrive eleven og ansvarliggøre forældrene for elevens læring og trivsel, mens elev og forældre forventes at indgå i samarbejdet som lyttende, opbakkende og forpligtede til at arbejde med de forhold, lærerne finder nødvendige. Spørgsmålet er dog, om og hvordan dette ulige magtforhold påvirker den ønskede inddragelse og involvering af forældre i skolen. 
I en opsamling af erfaringer om det gode skole-hjem-samarbejde udarbejdet af Danmarks Evalueringsinstitut (2012) fremhæves følgende:

\section{Når læreren tilrettelægger og fastlægger fokus for skole-hjem-samtalen, risikerer den let at bære præg af envejskommunikation. Det er vigtigt, at forældrenes holdninger og perspektiver indgår $i$ samtalen, og at samtalen giver tid og plads til spørgsmål fra forældrene. (Danmarks Evalueringsinstitut, 2012, s. 47)}

Vigtigheden af som forælder at få plads til at inddrage egne holdninger, perspektiver og ikke mindst at kunne give udtryk for eventuel modstand eller kritik, fremhæves ligeledes af Knudsen, i Magasinet Skolebørn:

\section{Skolen har stadig retten til at beskrive eleven, som det for eksempel sker til skole-hjem-samtalerne, men hois forældrene skal tage ansvar, må de også have ret til at udfordre lærerens beskrivelse af deres barn. Den udfordring har skolerne stadig ikke løst. (Magasinet Skolebørn, 2017)}

Fokus for denne artikel er, i lighed med Akselvoll (2016), at sætte fokus på, hvordan forældre og elever inden for det ulige magtforhold tilbydes forskellige deltagelsesmuligheder under samtalerne. Som et bidrag til den hidtidige forskning går jeg med afsæt i Basil Bernsteins teoriapparat dybere ned i selve samtalerne og udfolder, hvilke mekanismer der ligger bag den ulige magtfordeling, samt hvordan disse konkret kommer til udtryk. Med mit særlige fokus på de hhv. højt- og lavtpræsterende elevers samtaler bidrager artiklen tillige ved, i modsætning til flere af de tidligere studier ( $\mathrm{fx}$ Akselvoll, 2016; Dannesboe, 2012; Knudsen, 2010), at vise, hvordan der under samtalerne i varierende grad udøves modstand, kritik eller forhandling af lærernes vurderinger. Og i forlængelse heraf, at lærernes måde at forholde sig til disse forsøg på er markant forskellig, alt efter om eleverne af lærerne er kategoriseret som fagligt højt- eller lavtpræsterende. I relation hertil bidrager artiklen til praksisfeltet ved at rejse spørgsmålet om, hvorvidt der kan etableres et rum i samtalerne, hvor 'passende engagement ' ikke kun handler om at bakke op om skolen og lærernes vurderinger - og hermed undgå at rette for megen kritik, men også er forenelig med forhandling og udfordring fra elever og forældres side.

Med afsæt i ovenstående lyder artiklens forskningsspørgsmål som følger: 


\section{Hvilke muligheder har forældre til hhv. fagligt hojt- og lavtpræsterende elever og eleverne selv for at forhandle og udfordre lærernes vurderin- ger, og hvilke betydninger har disse muligheder for forskellige elevers og forældres reelle inddragelse ved skole-hjem-samtalerne?}

\section{Magt og kontrol}

Artiklens analyseledende begreber tager som nævnt afsæt i Bernsteins uddannelsessociologi med særligt fokus på begreberne klassifikation og rammesætning samt begrebsparret stemme og meddelelse (Bernstein, 1998; 2000; 2001). Disse begreber gør det muligt at studere kommunikation i pædagogiske praksisser med et særligt fokus på magt- og kontrolrelationer (se også Chouliaraki, 2001), hvorfor de er relevante i forhold til analysen af muligheden for at udfordre og forhandle i skole-hjem-samtalen. Herudover tager jeg afsæt i Bernsteins definition af det, han betegner som hhv. præstations- og kompetencemodellen. Disse modeller knytter sig til, hvilke kriterier der vægtes i evalueringen af eleverne. Hvor der i præstationsmodellen lægges overvejende vægt på elevens ydre produkter som fx deres opgaveafleveringer, testresultater og karakterer og dermed på elevernes faglige præstationer, lægges der i kompetencemodellen vægt på det, Bernstein kalder elevernes 'indre' dispositioner. Her er der fokus på elevernes personlige kompetencer som $\mathrm{fx}$ deres motivatoriske, følelsesmæssige og sproglige kompetencer (Bernstein, 1998; 2001, s. 100-102). I henhold til artiklens ærinde anvendes de præstations- og kompetenceorienterede kriterier til at få greb om de mekanismer, der er medvirkende til at skabe ulighed i skole-hjem-samtalerne.

Som udtryk for magtrelationerne i en pædagogisk praksis anvender Bernstein begrebet klassifikation som det, der etablerer grænser mellem forskellige kategorier som fx elev, lærer og forælder (Bernstein, 2001, s. 72). I artiklens analyser anvender jeg klassifikationsbegrebet til både at studere kommunikationen samt i min skelnen mellem højt- og lavtpræsterende elever. I lighed med Bernstein ligger min interesse ikke i at definere, hvad der kendetegner bestemte kategorier, om end det kan diskuteres, om jeg med klassifikationen mellem højt- og lavtpræsterende elever er med til at reproducere forståelsen af eleverne som værende enten fagligt dygtige eller mindre dygtige. Væsentligt er det dog at understrege, at jeg med anvendelsen af denne skelnen ikke henviser til faglig dygtighed som en essentialistisk størrelse og således til noget, som eleverne enten besidder eller ikke besidder, men derimod til, at 
elever i højere eller mindre grad formår at leve op til de koder for dygtighed, der eksisterer i skolen (se også Helms, 2017, s. 277). Mens magten kommer til udtryk i klassifikationer mellem kategorier, kommer kontrollen til udtryk i det, Bernstein betegner som rammesætningen, som helt grundlæggende handler om, hvem der kontrollerer hvad. I studiet af kommunikation i en pædagogisk praksis refererer rammesætningen således til den kontrol, der udøves i forhold til:

- Udvælgelsen af det, der kommunikeres

- Kommunikationens rækkefølge

- Kommunikationens tempo samt

- Kriterierne for, hvad der regnes for hhv. legitim og illegitim kommunikation (Bernstein, 2001, s. 80).

Såvel klassifikationen som rammesætningen kan være enten stærk eller svag. Ved en stærk klassifikation er der tale om skarp adskillelse mellem kategorierne, mens en svag klassifikation omvendt er karakteriseret ved mere utydelige grænser mellem kategorier. I relation til studiet af skole-hjem-samtalen vil en stærk klassifikation således betyde en skarp adskillelse mellem kategorierne lærer, elev og forælder, mens en svag klassifikation omvendt vil medføre mere flydende grænser mellem disse kategorier. En stærk rammesætning er kendetegnet ved en eksplicit regulering af kommunikationen, hvor det er læreren, der regulerer udvælgelsen, rækkefølgen, tempoet og kriterierne, herunder hvilke indlæg der regnes som hhv. legitime og illegitime. Ved en svag rammesætning vil elever og forældre omvendt have mere kontrol med de forskellige dele af rammesætningen og vil dermed i højere grad være med til at sætte dagsordenen for den legitime kommunikation (Bernstein, 2001).

Væsentligt i Bernsteins forståelse af forholdet mellem klassifikation og rammesætning er det dialektiske samspil mellem det, han betegner som 'stemme' og meddelelse (Bernstein, 2000, s. 204). Begrebet stemme henviser til deltagernes positioner i den pædagogiske relation - positioner, der kan være mere eller mindre definitive, afhængig af klassifikationens styrke. Magten kommer således til udtryk i nogle klassifikationsprincipper, som giver os hver vores særlige positioner eller stemmer - eksempelvis som lærer eller elev. Mens klassifikationsprincipperne tildeler os hver vores stemme, er det kontrollens manifestation i rammesætningen, der sætter betingelserne for at levere legitime meddelelser. Er rammesætningen stærk, er kontrollen over, hvad der regnes som hhv. legitime og illegitime meddelelser, tilsva- 
rende stærk, mens der ved en svag rammesætning er videre grænser for, hvordan man kan meddele sig (Ahrenkiel, 2004, s. 96-97).

\section{Metodisk afsæt}

Metodologisk henter jeg inspiration i den kritiske etnografi, hvori der ligger en ambition om at adressere uretfærdigheder inden for bestemte 'levede' domæner (Madison, 2012). Ambitionen herom består bl.a. i at afdække det, der ikke er umiddelbart synligt for os, at forstyrre det, der er, og hermed at belyse det, der tages for givet, ved at gøre underliggende magt- og kontrolforhold synlige (Madison, 2012, s. 5). Inspirationen fra den kritiske etnografi ligger således i tråd med mit valg af Bernstein, som deler opfattelsen af, at der eksisterer magt- og kontrolformer, der ikke er umiddelbart synlige, som kan være med til at gøre bestemte grupper af individer ugunstigt stillede. Det er således min ambition gennem analysen af, hvordan magt og kontrol udmønter sig i bestemte kommunikationsprincipper under skole-hjem-samtalerne, at skabe kritisk opmærksomhed omkring, hvordan disse principper kan sætte nogle forældre og elever i en ugunstig position (se også Helms, 2017, s. 122).

Artiklens analyser tager afsæt i observationer af 20 skole-hjem-samtaler, som udgjorde en del af min dataproduktion i forbindelse med min ph.d.-afhandling (Helms, 2017). Observationerne blev foretaget i hhv. en 8. og en 9. klasse på to 'almindelige' skoler på Sjælland, der begge rekrutterede bredt i forhold til elevernes faglige niveauer. I ønsket om at undersøge, om samtalerne udfoldede sig forskelligt, alt efter hvordan lærerne opfattede elevernes faglige niveau, udvalgtes samtalerne på baggrund af lærernes kategoriseringer heraf, såvel som på baggrund af, hvilke forældre og elever, der samtykkede til min tilstedeværelse. Efter aftale med elever, forældre og lærere båndoptog jeg samtalerne med en lille diktafon placeret midt på samtalebordet.

De følgende analyser tager afsæt i fire skole-hjem-samtaler med eleverne Tilde og Mikkel, der begge vurderes som fagligt lavtpræsterende, samt Malthe og Lisa, ${ }^{1}$ der begge er vurderet som fagligt højtpræsterende. I udvælgelsen af de fire samtaler har jeg lagt vægt på, at disse er eksemplariske for de mekanismer, der gør sig gældende for hhv. de højt- og lavtpræsterende elevers samtaler, og for netop at illustrere forskellene på disse er analysen 
opdelt i to dele, hvor første del omhandler samtalerne med de lavtpræsterende elever og anden del de højtpræsterende elever.

\section{Analysedel 1: De lavtpræsterende elever}

På begge skoler er skole-hjem-samtalerne relativt stærkt rammesat. Der er afsat 15 minutter pr. elev, og samtalerne er i udgangspunktet kendetegnet ved, at det er lærerne, der har kontrollen over kommunikationen og hermed for udvælgelsen og rækkefølgen af det, der skal tales om. Et gennemgående mønster i de lavtpræsterende elevers samtaler er, at disse i høj grad handler om, hvordan eleven bør ændre adfærd og tilgang til skolearbejdet.

\section{At skulle ændre sin adfærd}

Tilde går i 8. klasse, og til samtalen deltager hun selv, hendes mor, matematiklæreren Solveig samt fysiklæreren Bente. Tilde har tidligere gået på en anden skole og startede på Strandvigskolen for et år siden. Samtalen indledes af Solveig, der tager fat i, at Tilde synes, at matematik er meget svært, og at hun har en del faglige 'huller' i faget. Solveig understreger, at hun nok skal hjælpe Tilde, men samtalen drejes hurtigt over på, hvordan Tilde kan forbedre sin adfærd i undervisningen.

\section{Solveig: En ting, jeg rigtig godt kunne tænke mig, det var, at du havde lidt mere fokus. Og jeg ved godt, når ting er svare, så bliver det lidt nemt at falde fra og ikke lige få tingene op og ikke lige gå i gang, og ikke lige spørge. Men hois du lover mig, at du finder dine ting lidt hurtigt frem og går i krig og ikke småsnakker, så kan jeg lære dig meget, meget mere (...).}

Som det fremgår, savner Solveig, at Tilde er mere fokuseret og aktiv i timerne i stedet for at 'falde fra' og småsnakke. Henstillingen til, at Tilde bliver mere fokuseret og snakker mindre i timerne, understreges ligeledes af fysiklæreren Bente, og det, at Tilde må ændre sin adfærd, er således et gennemgående tema i samtalen.

I Mikkels samtale går flere af de samme mønstre igen som hos Tilde. Mikkel går i 9. klasse på Dyssehøjskolen, og da han snart skal gå ud af folkeskolen, handler hans samtale overvejende om, hvad han skal fremadrettet. Ved samtalen deltager han selv, begge hans forældre, dansklæreren Ruth og matematiklæreren Ole. Mikkel har et stort ønske om at gå direkte i gymna- 
siet efter 9. klasse, og samtalen indledes med, at Ruth spørger til Mikkels planer efter 9., hvortil han svarer, at han regner med at gå i gymnasiet.

\section{Ruth: (...) Så er det, jeg nu skal sige, for nu har vi jo ikke lige vidst, hoad du ville. At vi skal sige, at som det ser ud nu, så er det ikke lige det, vi vil anbefale dig $i$ forste omgang. Ole: Det ser ud som om, der mangler lidt mundtlighed.}

Akselvoll (2016) fremhæver, hvordan samtalerne med de elever, der har faglige eller sociale udfordringer, ofte centrerer omkring elevens 'mangler' og i forlængelse heraf, hvad elev og forældre skal gøre for at rette op på disse mangler (Akselvoll, 2016, s. 143-144). I mit studie var det dog et gennemgående mønster i de lavtpræsterende elevers samtaler, at det faktisk udelukkende var eleverne, der opfordredes til at ændre deres adfærd. På intet tidspunkt blev muligheden for, hvordan forældrene eller lærerne selv kunne støtte op om elevens faglige udvikling eller tilgang til undervisningen, drøftet. Med udgangspunkt i Bernsteins perspektiv på kriterierne for evalueringen, synes en forklaring på det stærke fokus på de lavtpræsterende elevers adfærd at hænge sammen med en særlig sammenfletning af de præstations- og kompetenceorienterede kriterier. Således træder der hos lærerne en forståelse frem af, at elevernes indre dispositioner eller kompetencer er en forudsætning for at præstere godt fagligt, eller sagt med andre ord, at den 'rette' adfærd ses som forudsætning for at opnå de tilstrækkelige færdigheder. Elevernes adfærd anses herved som både forklaringen og løsningen på deres faglige niveau. Det er, fordi Tilde ikke er engageret og aktiv nok i timerne, at hendes faglige niveau er for lavt, og det er, fordi Mikkel ikke er tilstrækkeligt mundtligt aktiv, at han ifølge lærerne bør vente med at gå i gymnasiet (se evt. Helms, 2017, s. 157).

Der er ikke noget nyt i, at lærere tillægger elevers adfærd i undervisningen betydning for deres faglige præstationer. Det, der er interessant, er dog, hvordan den stærke betoning af elevernes adfærd får afgørende betydning for de lavtpræsterende elevers og deres forældres muligheder for at udøve modstand og forhandle lærernes vurderinger under samtalen. Således synes forståelsen af elevernes adfærd som både forklaring og løsning på deres faglige præstationer at medføre en stærk individualisering, hvor det at udvise tilstrækkelig aktivitet, deltagelse og engagement i undervisningen bliver et spørgsmål om, som elev, at ville. At udvise de 'rette' indre dispositioner synes at træde frem som et individuelt anliggende, som noget 
'iboende', den enkelte elev kan finde frem fra sit indre, hvis viljen hertil blot er til stede (Helms, 2017, s. 186). I det følgende vil jeg illustrere, hvordan individualiseringen netop synes at spille ind på mulighederne for at forhandle vurderingerne i skole-hjem-samtalerne.

\section{Illegitime meddelelser}

Akselvoll (2016) peger på, hvordan forældre til elever med faglige og/eller sociale udfordringer ofte forholder sig overvejende passivt ved skole-hjemsamtalen. Om end der også i mit materiale kan spores en tendens hertil, er der dog flere af de lavtpræsterende elevers forældre, der forsøger at udøve en form for modstand. Tildes mor forholder sig overvejende passivt, men lidt inde i samtalen forsøger hun at forklare, hvorfor Tilde har nogle vanskeligheder i matematik.

\section{Tildes mor: Et af hullerne har at gøre med et skiftende antal matema- tiklærere på den forrige skole. 6 stykker eller sådan noget. \\ Solveig: Hold da op, det var mange! \\ Tildes mor: Det er rigtigt mange! Og alle regner lidt på forskellig måde.}

Solveig: Man gør tingene forskelligt. Sådan er det altid, når man skifter lærer. Så giver det et eller andet knæk. Men vi skal have dig til at rykke. (...) Så vær på og sig: 'Nu skal jeg lære det her.' (...) Så vær på og sig: 'Huit! Bøgerne frem. Fuit! Fokus! Luk af for de andre!'

Selvom Solveig anerkender, at det kan være problematisk at skifte lærere, vender hun igen hurtigt fokus mod Tildes fremadrettede læring med en tilkendegivelse af, at det vigtigste er, at hun holder fokus i undervisningen og anstrenger sig mere for at 'være på'. Samme opfordringer får hun også af Bente, da både Tilde og hendes mor forsøger at forklare, at den tidligere lærer stoppede pludseligt, og Tilde derfor ikke havde fysik i et halvt år.

\section{Bente: Men prov at hør her. Der er rigtig mange ting, der kan have gået galt, ikke også? Og jeg siger bare, at du skal hænge på nu, for så... til næste år. Alle de forsøg, vi også laver til næste år. Det er jo så også nogle af dem, man kan bruge til eksamen, ikke?}

Til dels anerkendes det igen, at Tilde kan have haft nogle uheldige oplevelser med de tidligere lærere, men alligevel formår Tildes og hendes mors medde- 
lelser ikke umiddelbart at rykke ved de eksisterende magt- og kontrolrelationer. Da Tilde allerede er tildelt en stemme som en elev, der ikke leverer en fuldt ud legitim adfærd, kan hun og moren altså ikke bortforklare det faglige niveau med henvisning til nogle tidligere lærere. Den stærke sammenfletning af de præstations- og kompetenceorienterede kriterier og den heraf følgende individualisering får således den betydning, at det er Tilde, der så at sige må arbejde med sig selv. Solveig og Bente 'ved' allerede godt, at det er Tildes manglende deltagelse, motivation og koncentration, der bremser hendes faglige udvikling, og ikke (kun) de tidligere lærere, hvorfor Tildes og hendes mors meddelelser ikke anses som helt legitime (Helms, 2017, s. 212).

Også i Mikkels samtale træder det frem, hvordan forståelsen hos lærerne er, at det er Mikkel selv, der må ændre sin tilgang til undervisningen. I samtalen forholder Mikkel og hans mor sig primært passive, mens hans far er mere aktiv i samtalen. Da begge lærere giver udtryk for, at de ikke vil anbefale Mikkel at gå direkte i gymnasiet, men i stedet tage 10. klasse først, dels fordi han har fået $02 \mathrm{i}$ fysik, og dels på grund af manglende mundtlig deltagelse i timerne, forsøger Mikkel dog et par enkelte gange at udøve en form for modstand. Først tilkendegiver han, at han oplever 10. klasse som et 'spildår', og senere påpeger han, at han godt tror, han kan klare at have fysik på C-niveau i gymnasiet, som det kræves. Mikkels forsøg på modstand godtages dog ikke, og Ole henviser igen til Mikkels karakterer.

\section{Ole: Men det er vigtigt så, at du har nogle stærke fag ud over, ikke? Og man kan se på engelsk og tysk: 4. Jamen, der følger du jo med på det her niveau, rimeligt, men ikke prangende, kan man sige. Det er ikke sådan, så du brillerer i fagene, tror jeg.}

I et forsøg på at bakke Mikkel op, forsøger hans far at forhandle lærernes vurdering

\section{Mikkels far: (...) altså jeg kan godt se, at det er selvfølgelig smadder xrgerligt at komme over og så knække nakken, fordi det er for svært. Omvendt synes jeg også, at det er smadder xrgerligt, hvis det er det, man gerne vil. Og Mikkel har hele tiden givet udtryk for, at han ikke vil i 10., for så står man så... hoad skal man så, ikke?}

Selvom faren anerkender lærernes vurdering ved at tilkendegive, at det selvfølgelig er uhensigtsmæssigt, hvis Mikkel 'knækker nakken' på gym- 
nasiet, forsøger han dog at appellere til lærernes forståelse for Mikkels store ønske om at komme direkte i gymnasiet. Mikkels far forsøger flere gange gennem samtalen at åbne op for, at Mikkel jo stadig har resten af 9. klasse til at 'give den en skalle', og betone, at han er indstillet herpå, men på trods af disse forsøg er det fast besluttet af de to lærere, at de vil anbefale Mikkel at gå i 10. klasse først. Flere gange understreger lærerne dog, at det ikke er deres beslutning, og at de blot vejleder Mikkel og hans forældre.

\section{Ruth: Nej, nej, men det er heller ikke... Vi er ikke dem, der bestemmer, vi vejleder bare. \\ Mikkels far: Nej, nej, men jeg synes også... jamen det er jo.... \\ Ruth: Og vi vejleder ud fra, hoad vi ved, ikke? \\ Ole: Det er jo noget, I sådan set selv bestemmer. \\ Mikkels far: Ja. \\ Ole: Og man kan bare sige... havde du varet min søn, så ville jeg sige, at du skal tage 10., og så skal du i øvrigt ikke være ked af det. Tværti- mod skal du være glad for det.}

Til trods for lærernes betoning af, at det ikke er dem, der bestemmer, er det ikke muligt for Mikkel og hans far at forhandle vurderingen og rykke ved magtrelationerne i samtalen. Ruths understregning af, at lærerne vejleder ud fra det, de ved om Mikkel, synes derimod at cementere de to læreres autoritet til at foretage en velovervejet vurdering af hans fremtidsmuligheder, og Mikkels far responderer også nærmest undskyldende og ender til sidst i samtalen med at samtykke og opgive at forhandle yderligere. Med afsæt i Bernsteins klassifikationsbegreb træder det tydeligt frem, at samtalen er kendetegnet ved en stærk klassifikation mellem læreren, der besidder den professionelle viden om Mikkel, på den ene side og forælderen, der ikke er professionel og således ikke helt kan vurdere sønnens faglige niveau på den anden. Interessant er det dog at bemærke, hvordan Ole til trods for den stærke klassifikation mellem elev, lærer og forælder samtidig overskrider klassifikationen mellem lærer og forælder. Med bemærkningen 'havde du været min søn, så ville jeg sige, at du skal tage 10.' overtager Ole nærmest forældrerollen og fungerer hermed opdragende over for Mikkels far med en underliggende betoning af, at det er det, han som far bør råde Mikkel til.

Tildes og Mikkels samtaler er begge kendetegnet ved en stærk klassifikation og rammesætning, hvor det helt overvejende er lærerne, der besidder kontrollen med kommunikationen. Det er lærerne, der udvælger, hvad der 
skal tales om, rækkefølgen af det, der skal tales om, og hvor længe, samt dem, der afgør, hvorvidt elever og forældres indlæg i samtalen regnes som legitime eller ej (jf. Bernstein, 1990, s. 37). For her at vende tilbage til Bernsteins begreber 'stemme' og 'meddelelse' er det stemmen, der sætter grænsen for, hvilke meddelelser der anses som hhv. legitime og illegitime, men samtidig kan meddelelsen også virke tilbage på stemmen, hvilket betyder, at vores måder at kommunikere på også kan være med til at udfordre og forhandle de eksisterende magtrelationer (Ahrenkiel, 2004, s. 96-97). Analyserne af de to samtaler peger dog på, at stemmen som fagligt lavtpræsterende, qua den stærke klassifikation, er så definitiv, at mulighederne for som elev og forældre at forhandle eller sætte spørgsmålstegn ved lærernes vurderinger er stærkt begrænsede. Selvom forældrene flere gange forsøger at forklare sig og appellere til alternative fortællinger om deres barn, lukkes disse forsøg på forhandling hurtigt ned. Når det at være fagligt lavtpræsterende i høj grad forbindes med elevernes adfærd og en heraf følgende fordring om at ændre denne, anses det således for illegitime meddelelser at 'skyde skylden' på tidligere lærere eller at sætte spørgsmålstegn ved lærernes vurdering af, at 10 . klasse er det rette valg for Mikkel. Det, at elevernes adfærd individualiseres og betragtes som et spørgsmål om, som elev, at ville være mere fokuseret, mundtligt aktiv og engageret i undervisningen, medfører dog ikke blot, at de lavtpræsterende elevers og deres forældres meddelelser regnes for illegitime. Det medfører også, at undervisningens og lærerens betydning for de to elevers deltagelsesmuligheder i undervisningen udgrænses. Således spørges hverken Tilde, Mikkel eller deres forældre på noget tidspunkt ind til, hvordan de oplever det at gå i klassen, undervisningen eller andre forhold, der kan have betydning for de to elevers tilgang til undervisningen.

I den følgende analysedel vil jeg vende mig mod samtalerne med de højtpræsterende elever og her belyse, hvordan deres muligheder for inddragelse ser ganske anderledes ud end de lavtpræsterende elevers.

\section{Analysedel 2: De højtpræsterende elever}

\section{Fortsæt den 'gode' adfærd}

Malthe går i 9. klasse på Dyssehøjskolen, og ved samtalen deltager han selv, begge hans forældre samt Ole og Ruth. Lisa går i 8. klasse på Strandvigskolen og har som den eneste elev i det empiriske materiale valgt ikke at deltage i samtalen, hvorfor det kun er lærerne Solveig og Bente samt Lisas forældre, der deltager. I et interview med Lisa fortæller hun mig, at hun finder det 
grænseoverskridende at sidde med ved samtalen, bl.a. fordi hun, med eget udtryk, finder det ubehageligt, at lærerne 'stirrer hende lige i øjnene'.

Den samme individualisering af eleverne, som vi så ved de lavtpræsterende elever, viser sig også i samtalerne med de højtpræsterende elever. En helt central forskel er dog, at disse elever i modsætning til de lavtpræsterende udviser den 'rette' vilje og indstilling til undervisningen. Dette kommer bl.a. til udtryk i lærerens indledende kommentarer til de to elever. Til Malthe siger Ruth:

\section{Du er jo en af de elever, som... hvorom vi plejer at sige, at vi egentlig ikke rigtig ved, hvad vi skal snakke om, for vi kan jo godt snakke om andre hyggelige ting, men din faglighed fejler jo ikke noget. Og din måde at være på og det hele fejler jo heller ikke noget. Så det er kun positivt herfra. Og du har selv lidt været inde på nogle ting, hvor du siger: 'Ej, nu får jeg ikke $12 i$ det hele', eller sådan noget $i$ den dur, ikke?}

Solveig indleder ligeledes samtalen vedrørende Lisa med at rose hende for såvel hendes faglighed som for hendes adfærd i undervisningen

\section{Solveig: Lisa er rigtig, rigtig dygtig til matematik. Og hun har et rigtig, rigtig godt fagligt overblik. Hun går i krig med det, hun skal, og hun følger undervisningen rigtig, rigtig fint.}

Der er, i modsætning til i de lavtpræsterende elevers tilfælde, ikke umiddelbart noget, hverken Malthe eller Lisa skal ændre; de skal blot fortsætte 'den gode adfærd'. Dette afstedkommer en række mekanismer i samtalen med de højtpræsterende elever, som står i modsætning til mekanismerne i de lavtpræsterende elevers samtaler:

- Eleverne og deres forældre træder ind i samtalen med langt mere positivt ladede stemmer

- Samtalen finder sted under en svagere rammesætning

- Udvælgelsen og rækkefølgen af indholdet for samtalen styres af lærerne såvel som elev og forældre

- Klassifikationen mellem lærer, elev og forælder er svagere og åbner op for et større spillerum for legitime meddelelser.

Når lærerne ikke har en bestemt dagsorden for, hvad eleven skal ændre, men snarere en dagsorden om, at eleven blot skal fortsætte den 'gode adfærd', løsnes der også op omkring kategorierne lærer, elev og forælder, hvilket 
samtidig medfører, at rammesætningen for at levere legitime meddelelser er svagere end i de lavtpræsterendes tilfælde. Dette vil jeg udfolde i det følgende.

\section{Læreren evalueres}

Den svagere rammesætning viser sig allerede ved Ruths indledende spørgsmål til Malthes utilfredshed med ikke at have fået 12 i karakter, hvor hun åbner op for hans perspektiver. Denne åbning griber Malthe med det samme.

\section{Malthe: Der var lige historie. Den forstod jeg ikke helt [henviser til sin historiekarakter].}

Ruth, der også underviser Malthe i historie, forsøger herefter at henvise til en opgave, som Malthe tilsyneladende ikke har klaret helt til et 12-tal og svarer videre:

\section{Ja. Men jeg ved godt, at du har ligget dér, ikke? Men altså 12 er jo også noget med, at man kan sige, ikke lige så dygtig som læreren, men næsten derhen ad, ikke? \\ Malthe: Der synes jeg også, at man skal skelne mellem forskellige fag. Jeg ved godt, at det kan være svært, fordi du har os $i$ så mange fag. Ruth: Nej, det synes jeg nu ikke. Men altså, det ved jeg godt. Den dis- kussion havde vi, og jeg har også sagt til dig, der er jo næste gang også, ikke?}

Malthe udøver gennem passagen en eksplicit modstand mod Ruths kategorisering af ham i form af karakteren 10, og på trods af Ruths forsøg på at forklare sig fortsætter han sin modstand med en nærmest medfølende kommentar om, at han godt ved, det kan være svært for Ruth. I modsætning til i Tildes og Mikkels samtaler kommer Malthes samtale også til at handle om, hvad Ruth skal forbedre. Hermed formår Malthe at rykke ved de eksisterende magt- og kontrolrelationer og således at bryde med klassifikationen mellem læreren, der evaluerer eleven, og eleven, der modtager evalueringen. Knudsen (2010) peger netop på, hvordan elever og forældre har stærkt begrænsede muligheder for at udøve modstand, idet der ved skole-hjem-samtalen er udstukket nogle særlige positioner, der handler om, at elev og forældre forventes at bakke op om lærernes ytringer. Dette gør sig gældende i de lavtpræsterende elevers samtaler, hvorimod disse positioner 
udfolder sig anderledes for de højtpræsterende elever. På trods af at Malthe udøver en eksplicit modstand i forhold til Ruths forklaringer, bliver hans meddelelser alligevel anset som mere legitime end modstanden i Tilde og Mikkels samtaler. Dette viser sig flere steder i løbet af samtalen, bl.a. i afslutningen af denne, hvor Ruth igen åbner op for såvel Malthes som hans forældres perspektiver.

\section{Ruth: (...) Har I noget, I vil spørge om eller vide mere om eller et eller andet, så fyr løs.}

Malthe tager hurtigt ordet og udtrykker, at han er utilfreds med Ruths kommunikation omkring, hvor mange sider de har haft for i 'Det forsømte forår'. Malthe har opfattet, at de havde færre sider for, end tilfældet var, hvorefter Ruth nærmest undskyldende gør rede for, at hun har sat sidetal på lektierne for at hjælpe, idet hun oplever, at der er flere i klassen, der ikke får læst. Malthe er dog endnu ikke tilfreds med Ruths svar.

\section{Malthe: Ja, men det er bare vores forventning, at du gerne må gøre det lidt mere klart, at på det dér tidspunkt skal vi læse det dér. \\ Malthes far: Det var mere det med kommunikationen med det. Ruth: Det er det, der hedder en kommunikationsbrist, ikke?}

Igen formår Malthe at bringe Ruth under evaluering og udtrykke hans forventninger til hende som lærer. Den modstand, han her udøver med opbakning fra hans far, anerkendes af Ruth, hvormed meddelelserne igen legitimeres på en helt anden måde end i de lavtpræsterendes samtaler. Således ser vi, hvordan Ruth, trods forsøg på at forklare sig, ender med at indrømme, at der har været tale om en kommunikationsbrist fra hendes side, ligesom hun med bemærkningen 'der er jo næste gang også, ikke?' åbner op for, at karakteren kan ændres til 12 næste gang.

I Lisas samtale er det hendes mor, der formår at tage kontrollen med kommunikationen og bringe skolen og lærerne under evaluering.

I den følgende passage udtrykker Solveig et ønske om, at Lisa deltager mere mundtligt i timerne. Selvom Lisa leverer den 'rette adfærd' og helt gennemgående i samtalen mødes med ros, savner Solveig, at Lisa også bidrager mundtligt, fordi hun netop har godt styr på matematikken. 
Solveig: (...) og så mundtligt skal hun mere på, for hun har så meget godt. Så der skal hun på, og jeg ved godt, at hun er måske ikke er den, der synes, det er allersjovest at sige en masse, altid.

Lisas mor: Det tror jeg nu nok. Det må jeg lige sige! Jeg tror ikke, det er fordi, hun ikke har noget at ville sige eller...

Solveig: Nej, nej, men jeg tænker måske lidt generthed.

Lisas mor: Det kunne der måske være. Og du spurgte lige her til sidst om uro, og om der stadigvak var meget uro. Altså hun oplever det dér uro jo.

Solveig: Ja, men det er der også, altså der kan godt være noget uro en gang imellem. Men jeg vil sige, jeg synes måske ikke, det er, når jeg gennemgår. Jeg synes måske mere, det er, når jeg slipper dem løs. Lisas mor: Jeg tænkte bare $i$ al almindelighed. (...) Altså, det Lisa synes er svarest, det er den uro, der er her, og så er det det dér med vikartimerne. Hun synes, det er pinligt og forfxrdeligt at se på, at lærerne står og siger... eller at de ikke kan styre det. Det bryder hun sig ikke om.

Solveig: Det er jo egentlig heller ikke så fedt.

Lisas mor: Nej, og hun sætter virkelig ord på det!

Lisas mor formår først at sætte spørgsmålstegn ved Solveigs vurdering af, at Lisa ikke har lyst til at sige noget i timerne, og hernæst at dreje samtalen over på den uro, Lisa oplever i klassen generelt, herunder når der er vikar. Med bemærkningen om, at lærerne ikke kan 'styre' eleverne, og hvor ubehageligt Lisa oplever dette, får moren ændret samtalen til i højere grad at handle om, at skolen og lærerne står med en udfordring - ikke Lisa. Hermed ændres rammesætningen, og det bliver Lisas mor, mere end lærerne, der styrer udvælgelsen og rækkefølgen af det, der skal tales om. Moren udøver en eksplicit modstand, der også indeholder en kritik af lærernes måde at håndtere uroen på, og som i Malthes tilfælde anerkendes denne kritik af Solveig, der understreger, at 'det jo heller ikke er så fedt'.

\section{Opsamling og konklusion}

Som skitseret indledningsvist peger såvel Danmarks Evalueringsinstitut (2012) som Knudsen (2010) på, hvordan en reel inddragelse af forældrene indebærer, at deres perspektiver, holdninger og spørgsmål får plads i skole-hjem-samtalen. Ligeledes indebærer det at skulle tage ansvar for sit barns 
læring og trivsel i skolen også, at forældrene har ret til at udfordre lærerens beskrivelser (Magasinet Skolebørn, 2017).

Gennem artiklen har jeg vist, at mulighederne for inddragelse, herunder for det at forhandle og udøve modstand i samtalerne, er markant forskellige for de hhv. højt- og lavtpræsterende elever og deres forældre. Mens forsøgene på forhandling hurtigt lukkes ned i de lavtpræsterende elevers tilfælde og anses som illegitime, formår de højtpræsterende elever og deres forældre, til trods for både eksplicit modstand og kritik af lærerne, at få anerkendt deres meddelelser som legitime. Mulighederne for reel inddragelse i samtalen hænger sammen med en særlig sammenfletning af de præstations- og kompetenceorienterede kriterier, som lærerne lægger til grund for evalueringen af den enkelte elev. I lærernes vurderinger fremtræder således en forståelse af, at elevernes kompetencer - dvs. deres adfærd i og tilgang til undervisningen - er både forudsætning for og forklaring på, hvordan de præsterer rent fagligt. Denne forståelse medfører videre, at de fagligt lavtpræsterende træder ind i samtalen, ikke blot med stemmen som lavtpræsterende, men også med stemmen som en elev, der bør ændre sin adfærd.

Omvendt træder de højtpræsterende ind i samtalen med stemmer som elever, der allerede leverer den 'rette adfærd', og som derfor ikke i synderlig grad skal ændre noget. De forskellige stemmer, eleverne på forhånd er tildelt, får afgørende betydning for styrken af klassifikationen og rammesætningen ved samtalen og i forlængelse heraf, hvorvidt elevers og forældres meddelelser anses for legitime eller ej. Når lærerne ikke har noget at udsætte på elevens adfærd, åbnes der i langt højere grad op for elevers og forældres perspektiver, mens forståelsen af manglende vilje hos de lavtpræsterende elever til at ændre deres adfærd medfører, at det bliver illegitimt at forsøge at (bort)forklare eller forhandle lærernes vurderinger. Samtidig med at klassifikationerne og rammesætningen som udgangspunkt er svagere i de højtpræsterende elevers samtaler, formår eleverne og forældrene også her at svække klassifikationen og rammesætningen yderligere under samtalen og herved styrke legitimiteten i deres meddelelser. Dette kommer eksempelvis til udtryk, når lærerne gøres til genstand for evaluering.

Omvendt er klassifikationen og rammesætningen stærk gennem hele samtalen med de lavtpræsterende elever og deres forældre, hvis meddelelser ikke formår at udfordre de givne stemmer. Her forstærkes rammesætningen og klassifikationen derimod i løbet af samtalen. Mens individualiseringen af den lavpræsterende elev som værende den eneste, der kan skabe forbedring, består, opløses individualiseringen hos de højpræsterende ved at trække 
skolen og lærerne ind som nødvendige aktører i forhold til elevens trivsel og faglige udvikling.

I relation til spørgsmålet om reel inddragelse i skole-hjem-samtalen er det således en central pointe $i$ artiklen, at forskellige elever og forældre træder ind i samtalen med ulige stemmer, men at denne ulighed også forstærkes under selve samtalerne. Mulighederne for netop at bringe forhold frem i lyset, der kan have afgørende betydning for elevernes adfærd og tilgang til undervisningen, udgrænses således i de lavtpræsterende elevers tilfælde. Hvis skole-hjem-samarbejdet, herunder skole-hjem-samtalerne, skal være med til at øge elevernes læring og trivsel, synes det problematisk, at forhold, der kan have afgørende betydning for netop læring og trivsel, ikke får plads i forhold til de elever, der i forvejen har sværest ved at imødekomme lærernes forventninger. Ligeledes synes det problematisk, hvis samtalen lukker sig om en snæver fokusering på den lavtpræsterende elevs 'mangler' frem for at åbne sig til et fokus på de kvaliteter, kompetencer og færdigheder, eleven har, og hvordan disse i et samarbejde mellem lærere, elev og forældre kan bidrage til arbejdet med elevens faglige og personlige udvikling - samt ikke mindst elevens trivsel i skolen.

Med denne artikel har det været intentionen at bidrage til såvel forsknings- som praksisfeltet ved at belyse nogle af de mekanismer, der ligger bag den ulige magtfordeling, der gør sig gældende for forskellige forældre og elever i skole-hjem-samtalen, og ikke mindst, hvordan disse mekanismer kommer konkret til udtryk i samtalen. Som et nyt bidrag til den hidtidige forskning har jeg vist, hvordan det at få plads til at inddrage egne perspektiver i samtalen ikke kun handler om at levere et 'passende engagement', at bakke op om skolen og tage ansvar for elevens læring samt hermed at undgå at udøve modstand eller rette kritik (jf. tidligere studier på feltet). Dette handler i høj grad også om den stemme, eleverne i forvejen er tildelt. Således har jeg illustreret, hvordan de højtpræsterende elevers og forældres meddelelser, til trods for at disse er langt mere kritiske end de lavtpræsterendes, alligevel anses som mere legtime. For i relation hertil at vende tilbage til Knudsen (2010), synes forældres og elevers modstand, forhandlingsforsøg eller direkte kritik primært at blive opfattet som 'upassende brud', når det gælder de lavtpræsterende elever og deres forældre. Opbaknings- og ansvarsdiskursen (Knudsen, 2010) synes således overvejende at gøre sig gældende for denne gruppe elever og forældre.

Artiklens analytiske pointer udgør ligeledes et bidrag til praksisfeltet, idet der sættes fokus på vigtigheden af som lærer at lytte til og åbne op for 
alle forældres og elevers perspektiver, uanset den stemme, eleverne træder ind til samtalen med. Artiklens intention er ikke at udpege lærerne som 'skyldige' i en (re)produktion af ulighed. Den måde, lærerne forholder sig til forskellige elever og deres forældre på, må afgjort forstås som indlejret i samfundsmæssige, skolepolitiske og pædagogiske diskurser, som også kan sætte sig 'bag om ryggen' på de professionelle (for uddybning se Helms, 2017, s. 261-267; 87). Derfor ser jeg det som artiklens måske vigtigste bidrag til praksisfeltet at skabe opmærksomhed omkring de ulighedssættende mekanismer, der kan gøre sig gældende i skole-hjem-samtalen, og muligvis anspore til et udviklingsarbejde blandt skolens professionelle i forhold til, hvordan der kan skabes rum for, at også de lavtpræsterende elevers og deres forældres perspektiver og eventuelle modstand bliver legitime bidrag i skole-hjem-samtalen. Et udviklingsarbejde kunne for eksempel bestå i at undersøge, om skole-hjem-samtalen som koncept kan udformes eller fornyes på måder, der øger ligheden i forældres og elevers muligheder for inddragelse, således at det også anses som 'passende engagement' at udfordre eller forhandle lærernes beskrivelser og vurderinger.

At skabe rum for modstand og udfordringer åbner, som vist $i$ analysen, også op for, at skolen, læreren og undervisningen kan blive genstand for evaluering, men hvis vi som skole forventer, at alle forældre og elever skal tage ansvar, lytte og vise tillid, må skolen gøre det samme overfor alle forældre og elever - ellers kan vi ikke tale om et reelt samarbejde mellem skole og hjem.

\section{Referencer}

Aarseth, H. (2014). Lyst til læring eller 'fit for fight'? Middelklassefamiliens læringskulturer. I: Nielsen, H.B. (red.) Forskjeller i klassen. Nye perspektiver på kjønn, klasse og etnisitet $i$ skolen (s. 168-188). Universitetsforlaget.

Ahrenkiel, A. (2004). Kontrol og dynamik i pædagogiske processer - Et diskursanalytisk studie af kommunikation i en "usynlig" pædagogisk læringskontekst med daghøjskolen som eksempel. Ph.d.-afhandling. Roskilde Universitet.

Akselvoll, M.Ø. (2016). Folkeskole, forældre, forskelle-skole-hjem-samarbejde og forældreinvolvering $i$ et forældreperspektiv. Ph.d.-afhandling. Roskilde Universitet.

Bernstein, B. (1990). Class, Codes and Control: Volume 4 - The Structuring Of Pedagogic Discourse. Routledge.

Bernstein, B. (1998). Class and Pedagogies: Visible and Invisible. I: Halsey, A.H., Lauder, H., Brown, P., \& Wells, A.S. (red.), Education: Culture, Economy, and Society (s. 59-79). Oxford University Press.

Bernstein, B. (2000). Pedagogy, symbolic control and identity: Theory, research, critique (revised edition). Rowman \& Littlefield. 
Bernstein, B. (2001). Pædagogiske koder og deres praksismodaliteter. I: Bayer, M., \& Chouliaraki, L. (red.), Basil Bernstein - Pædagogik, diskurs og magt (s. 70-82). Akademisk Forlag.

Børne- og undervisningsministeriet (2020). Skole-hjem-samarbejde. https://www.uvm.dk/folkeskolen/organisering-og-ledelse/foraeldrenes-rolle/skole-hjem-samarbejde

Chouliaraki, L. (2001). Pædagogikkens sociale logik - en introduktion til Basil Bernsteins uddannelsessociologi. I: Bayer, M., \& Chouliaraki, L. (red.) Basil Bernstein - Pædagogik, diskurs og magt (s. 26-69). Akademisk Forlag.

Danmarks Evalueringsinstitut (2012). Det gode skole-hjem-samarbejde med forældre i udsatte positioner. Erfaringer fra seks skoler med stærk praksis. Rapport.

Dannesboe, K.I. (2012). Passende engagement og (u)bekvemme skoleliv. Et studie af børns navigationer mellem skole og familie. Ph.d.-afhandling. Aarhus Universitet.

Dannesboe, K.I., Kryger, N., Palludan, C., \& Ravn, B. (2012). Hvem sagde samarbejde? Et hverdagslivsstudie af skole-hjem-relationer. Aarhus Universitetsforlag.

Desforges, C. with Abouchaar, A. (2003). The impact of parental involvement, parental support and family education on pupil achievements and adjustment: A literature review. Forskningsrapport RR433, Dept. for Education and Skills, United Kingdom.

Helms, S. (2017). (U)Synlig evaluering $i$ skolen - et studie af elevplanens rekontekstualisering $i$ praksis. Ph.d.-afhandling. Roskilde Universitet.

Knudsen, H. (2010). Har vi en aftale? - magt og ansvar i mødet mellem folkeskole og familie. Nyt fra Samfundsvidenskaberne.

Kryger, N. (2012). Ungdomsidentitet - mellem skole og hjem. I: Dannesboe, K., Kryger, N., Palludan, C., \& Ravn, B. (red.), Hvem sagde samarbejde? Et hverdagslivsstudie af skole-hjem-relationer (s. 89-130). Aarhus Universitetsforlag.

Kryger, N. (2015). Det intensiverede samarbejde mellem institution og hjem under den tredje institutionalisering af barndommen. Dansk Pædagogisk Tidsskrift, 4(2015), 62-69.

Madison, D. S. (2012). Critical Ethnography: Method, Ethics, and Performance. Sage Publications.

Magasinet Skolebørn (2017). Temanummer: Forældrenes rolle i skolen. Skolebørn, 2017(1). http://www.skoleborn.dk/feb_2017/index.html

Nordahl, T. (2008). Hjem og skole. Hvordan skaber man et bedre samarbejde? Hans Reitzels Forlag.

Palludan, C. (2012). Skolestart - et følsomt forældrearbejde. I: Dannesboe, K.I., Kryger, N., Palludan, C., \& Ravn, B. (red.), Hvem sagde samarbejde? Et hverdagslivsstudie af skole-hjem-relationer (s. 21-54). Aarhus Universitetsforlag.

Ravn, B. (2011). Skole-hjem-samarbejdets historie. Dansk Pædagogisk Tidsskrift, 2011(1). 